\title{
Practice and Experience Reference of the Number Portability Policy in Typical Countries or Regions
}

\author{
Meijuan Li* \\ School of Economics and Management \\ Yunnan Normal University \\ Kunming 650500 \\ E-mail: limeijuan927@163.com
}

\author{
Lili Zhang \\ School of Statistics and Mathematics \\ Yunnan University of Finance and Economics \\ Kunming 650221
}

\begin{abstract}
To promote the effective implementation of the number portability policy in China's telecom industry, we analyze the practice of number portability policy in countries, such as Japan, Korea and Hong Kong, and summarize their experiences in the practice of number portability. Our results show that these countries or regions have carried out a positive publicity and effective supervision in the implementation of the number portability policy, in order to to improve the telecom market competition pattern through the number portability policy. The telecom advisory body has formulated a reasonable number portability business process and charges, established the implementation details of the number portability policy and the conduct norm of telecom operations with law form. Through these means and methods, the regulatory authorities can timely deal with the user's problems which have been arised in the number portability process, and severely punish behavior obstructed the implementation of the number portability policy.
\end{abstract}

Keywords-number portability; policy practice; experience reference

\section{INTRODUCTION}

The number portability refers that a telecom operator's users can carry their original number into another telecom operator, and can enjoy this carrier's telecom services [1]. After China's telecom industry has reorganized in 2008, in order to promote the coordinated and orderly development of the telecom market, the industry and ministry of information technology as the regulatory body of the telecom industry has introduced a variety of regulatory measures, the number portability policy which is considered effective regulation measures comes into being. November 2010, the number portability policy has carried out the pilot in Tianjin, Hainan. September 2014, the pilot has extended to Jiangxi, Hubei and Yunnan. Since the number portability policy carries out the pilot, its effects in China telecom industry are not obvious, which mainly embodies in the low transfer application rate, low success rate after application, handled business for a long time, service quality affected after the transfer. These phenomenons are caused by a variety of reasons, for example, telecom operators set up a variety of agreements with the user, the users can not apply for portability in the agreement period, which bundles the user in the various agreements, and set up a variety of obstacles to complex simple process when the users transact the number portability, and so on.

With the implementation of the number portability pilot, telecom operators have to develop a reasonable price in order to improve the telecom services quality. The propaganda and supervision of the number portability policy in the telecom industry are necessary guarantee to promote the smoothly and effective implementation of the number portability policy [2] In view of the number portability policy practices in the typical countries or regions, due to the development of the telecom market in different countries, the implementation methods and regulatory methods of the number portability policy are also different, resulting into the different implementation effect [3]. This paper will summarize the practical and experience of some typical countries or regions to provide reference for the implementation of the the number portability policy in China telecom industry, induce the number portability policy to play a more effective role, and further achieve policy expectations.

\section{PRACTICE AND EXPERIENCE REFERENCE OF THE NUMBER PORTABILITY POLICY IN JAPAN}

\section{A. Implementation of the number portability policy in Japan}

Japan is not only the most abundant in world's mobile internet operating experience, but also the most mature country of telecom market. In 2003, Japan set up a research team of the number portability policy, consulted and listened to suggestion of the professional organizations and personnel through the forum, carried out consultation and investigation on the implementation of the number portability policy for telecom operators and telecom users, and formulated the relevant rules of the number portability policy in 2004.According to statistical data of Japan Electrical Communications Enterprises Association, September 30, 2006 the number of mobile users achieved about 93.8 million, the mobile phone penetration rate is $75.7 \%$, the competition of three telecom operators is an unbalanced situation, the mobile subscribers of NTT DoCoMo,KDDI and Softbank Mobile accounted for $55.5 \%, 28.2 \%$ and $16.3 \%$ of the mobile market.

At the same time, according to the statistical data of Japan Electrical Communications Enterprises Association, the 
penetration rate of mobile phones is obtained according to the proportion of the national mobile number users in the national population. Since one person can have multiple mobile phone numbers, the penetration rate of mobile phones may exceed $100 \%$. The penetration rate of Japan's mobile phone in 2005 achieved $71.8 \%$, with the prosperity of the telecom market, the penetration rate of Japan's mobile phone in 2011 had even exceeded 100\%.Telecom market in Japan has achieved a certain saturation state, which multiple numbers are owned by one person lead to more and more scarce of number resources. Therefore, the effective implementation of the number portability policy which is ensured can improve the competition pattern of unbalanced telecom market [4].

October 24, 2006,Japan began to implement the number portability policy, the business process and charge way of the number portability make the following provisions: (1) In terms of process about the number portability, if the mobile users of NTT DoCoMo, Softbank Mobile and KDDI operators need to replace the their operator, they apply for the number portability authentication code for removing the operator, after obtaining the verification code, the applicants carry the verification code to the business point of new operator, they can transfer to the new operators with the original number after they sign a new network agreement, and enjoy the services provided by the new operators. The processing time is not more than 1 hour. (2) In terms of transfer fee about the number portability, the way that the carrying out parties and carrying parties are charged charges for users in the using the number portability business of the three telecom operators, and which only pay 2100 yen (about $30 \%$ of telecom operators ARPU) for carrying out operator will be able to successfully carry out from the current operators. Which pay 2835 yen for the carrying parties will carry to the new operator's network. But in the actual implementation of the business process, the carrying operators bring benefit for the carrying user, all users that apply for accession can carry exempt from the fee.Some operators also introduce promotions which user points deduct part of the transfer costs. Japan allows all mobile users to freely select telecom service providers in NTT DoCoMo, Softbank Mobile and KDDI without changing the mobile number.

\section{B. Implementation effect of the number portability policy in Japan}

According to the statistical data of Japan Electrical Communications Enterprises Association, as the number of mobile subscribers owned by telecom operator's accounts for the total number of mobile subscribers in the country, we may obtain the market share of the telecom operators. Figure 1 shows that the implementation of the number portability policy allows mobile users to more easily replace the telecom operators, which makes Japan's domestic telecom market competition become increasingly fierce. With the implementation of the number portability policy, the competitive landscape between telecom operators is also undergoing major changes.

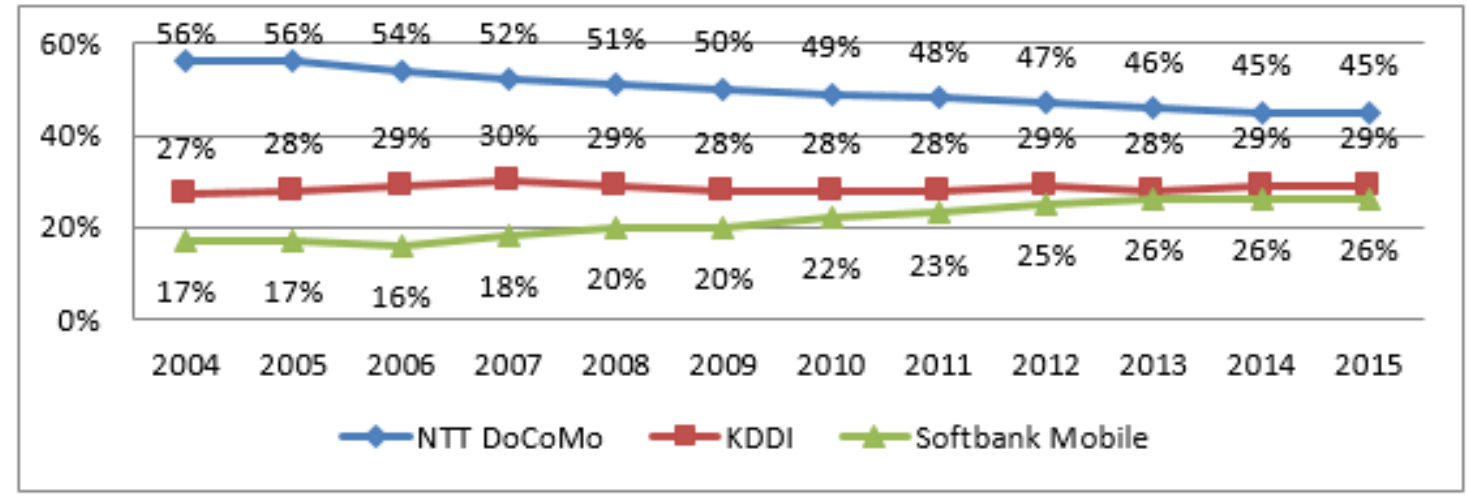

Fig. 1. Market share of Japanese telecom operators in 2004-2015

Since the number portability policy was implemented in 2006, the high tariffs of NTT DoCoMo let off-line rate to substantially increase. From Figure 2, we can see that the market share of NTT DoCoMo that is a strong operator, was declining after the implementation of the portability policy. In 2010, NTT DoCoMo's market share fell below 50\%. However, after the implementation of the number portability policy, KDDI's market share in 2007 was a small increase, it flexibilitily drawed up a favorable price, provided star business of music download and good service quality, upgraded its own CDMA 2000 network, which made it the fastest mobile network in Japan at that time. Softbank Mobile is the biggest beneficiary after the implementation of the number portability policy, it introduced promotional activities which was used by its internet users in the domestic telephone and inter-SMS free, focused on the development of mobile terminal equipment, introduced different types of terminal equipment with different needs of consumers, attracted consumers with continuous innovation, fully seized the new opportunities brought by the number portability policy, which made it stand out in the telecom market competition, the market share was continuous expansion and was $26 \%$ in 2015.

\section{Implementation experiences of the number portability policy in Japan}

Japan has achieved a positive role for the improvement of the telecom market competition pattern through the implementation of the number portability policy, which is inseparable with effective supervision of the telecom industry in Japan [5]. Firstly, in 1985, Japanese government began to formally implement the revised "Electric Communication 
Business Law", before implementation of the number portability policy, the Japan revised some of the provisions, which provides the appropriate legal basis for the regulatory agencies, made a corresponding adjustment for the regulatory thinking of the telecom industry, from pre-supervision transforming into intermediate and ex-post regulation. Secondly, Japan established the Telecom Industry Dispute Settlement Committee in November 2001, which was independent of Japan's general government. The Committee provided professional advice for Japan's general government, analyzed new problems in the telecom market, and proposed a concrete solution of the problem, which was conducive to solve the contradictions between the telecom regulator, telecom operators and consumers. Finally, Japan's general government cooperates with professional research institutions, draws up telecom tariff function and designs calculation model, shows the development of telecom tariff level for all telecomuser, and contrasts telecom tariff level before and after the implementation of the number portability policy, so that consumers can understand the positive role of the number portability policy, and it lays a certain foundation for the promotion of the number portability policy [6].

\section{PRACTICE AND EXPERIENCE REFERENCE OF THE NUMBER PORTABILITY POLICY IN KOREA}

\section{A. Implementation of the number portability policy in Korea}

There are three major telecom operators, such as SKT, KTF and LGT in Korea telecom market, SKT dominates the Korean's telecom market with long-established brand reputation, large-scale coverage of network station and successful marketing strategy. In 2003, SKT's market share was $53 \%$. The penetration rate of mobile phones in Korea reached $75.9 \%$ in 2003 , the mobile communication market gradually reached the saturation state, the new adding mobile users showed a downward trend. In order to struggle more market share, the new adding users was not only increasingly difficult, but also faced higher marketing costs. Therefore, the Ministry of Information and Communication (MIC) hoped to roll out the number portability policy which improved the current situation of the telecom market competition, and researched the policy feasibility and cost-benefit. The results show that the implementation of the number portability policy benefits most of consumers, effectively avoids the switching costs which the replacement of operators arises, reduces competition barriers , and promotes the effective competition in the telecom market [7].

On January 1, 2004, Korea began to implement the number portability policy, the business process and charge way of the number portability make the following provisions:(1)In terms of process about the number portability, users who require the portability business should apply for the caring operators, after the carrying operators verifies the identity of the mobile users who want to carry out from their initial operators, these users can successfully apply for portability business, processing time is only 30 minutes to 1 hour.(2) In terms of transfer fee about the number portability, telecom operators will charge 1,100 won (about $2.5 \%$ of telecom operators' ARPU) for the transfer users.

Taking full account of the market share status of the three telecom operators, Korea takes a phased form of implementation of the number portability policy, let the policy gradually carry out from local to the whole. The policy makes the weak telecom operators developed. The implementation process and program of the number portability policy in Korean followed as: January 1, 2004, SKT, that was strong telecom operator having a larger market share, firstly implemented the number portability policy. Korean only allowed SKT's mobile users to transfer their original number to KTF and LGT, did not let KTF's and LGT's mobile network users transfer their original number to the SKT, the KTF's and LGT's mobile network users could not transfer each other. July 1, 2004, KTF began to implement the number portability policy, SKT's and KTF's mobile users could be portability to any telecom operators, but LGT's mobile users could not transfer to SKT and KTF. January 1, 2005, LGT began to implement the number portability policy, mobile users could freely choose telecom operators to transfer among SKT, KTF and LGT [8].

\section{B. Implementation effect of the number portability policy in Korean}

According to the statistics stata of Korea Statistical Information Service Center, as the number of mobile subscribers owned by telecom operators accounts for the total number of mobile subscribers in the country, we may obtain the market share of the telecom operators (Figure 2). With the implementation of the number portability policy, in order to obtain new users, Korea's three telecom operators adopted low-price strategy to attract users transferring network, which resulted into a significant decline in the tariff level of the Korean telecom industry. The phased implementation of asymmetric number portability policy led to a significant outflow of SKT's users and gradual decline of SKT's market share, which fell below 50\% in 2011.Korea strictly regulated market share of the telecom industry, provided that the market share of any telecom operators should be controlled below $50 \%$, if the market share was more than $50 \%$, the telecom operator not only could not add new users, but also developed new users for other operations. Therefore, the implementation of the number portability policy was mainly to control the SKT market share, the policy had basically achieved the desired effect. LGT that was non-dominant telecom operators, had more gains, and its market share increased from $16 \%$ in 2004 to $19 \%$ in 2007. 


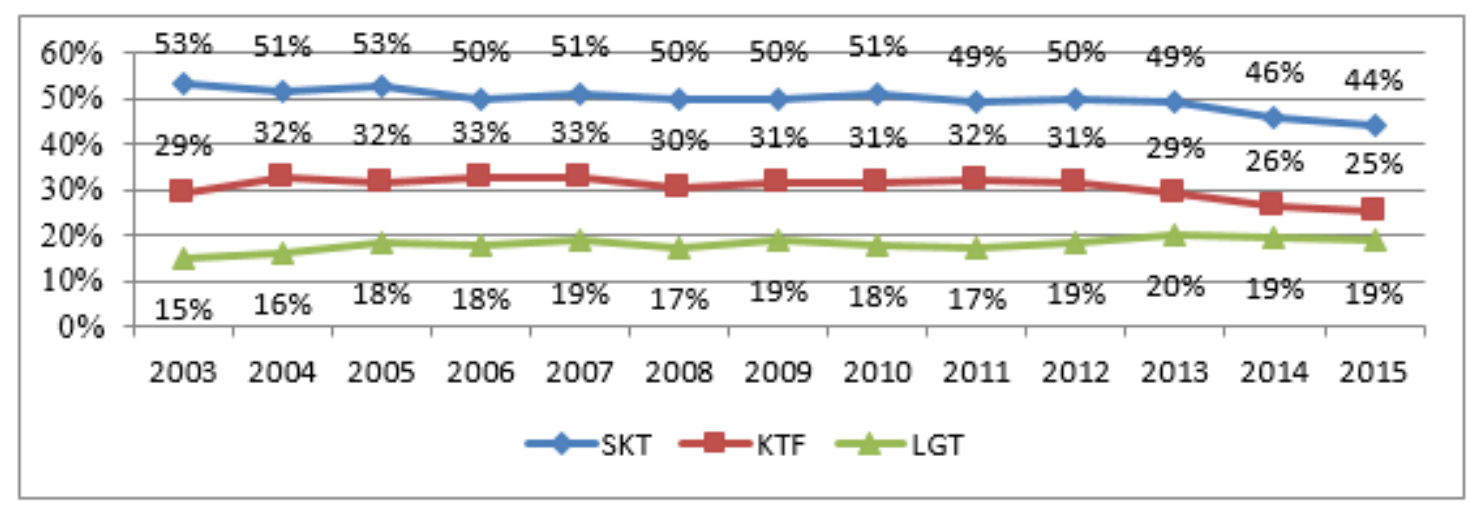

Fig. 2. 2003-2015 Korean telecom operators market share trend

\section{Implementation experiences of the number portability policy in Korea}

The reasons that the number portability policy in Korea can achieve good effect are as follows: firstly, Korean Communications Commission carries out a strong supervision with the telecom market after the implementation of the number portability policy. SKT that is the leading implementation of the number portability policy, facing a huge pressure of user transfer, had taken a negative attitude to response the number portability policy, prevented mobile users from using portability services based network failure. The three telecom operators had taken a variety of ways to subsidize the user's mobile phone, and locked the user signed a long-term contract with the form of subsidies. As a result of the more irregularities, Korea Communications Commission severely warned and punished three telecom operators: it penaltied SKT for its violation advertisements to users and 1.5 billion won fine. Because of retaining users' illegal marketing activities, SKT was penaltied 500 million won; KTF and LGT also were punished 250 million and 150 million won, because of refusing users' transfer.

Secondly, the new problems caused by the implementation of the number portability policy have also aroused the attention of the Ministry of Information and Communications of Korea. February 29, 2008, Korean Ministry of Information and Communication, Korea Communications Commission and Korea Broadcasting Committee were reorganized and form a new Korea Communications Commission (KCC), they drastically modified Korea's "Basic Law of Telecommunications", adjusted the regulatory functions of Korea Communications Commission, supplemented and modified the regulatory authority in order to accommodate the new situation in the telecom market competition. Finally, because the telecom operators let a substantial increase of telecom marketing costs in order to attract more users, so that the overall profitability of the telecom industry declined. In May 2010, Korea Communications Commission made a new requirement for telecom operators that the their marketing expenses should not exceed $22 \%$ of their sales, which maintained the competition order of telecom market.

\section{PRACTICE AND EXPERIENCE REFERENCE OF THE NUMBER PORTABILITY POLICY IN HONG KONG}

\section{A. Implementation of the number portability policy in Hong Kong}

The booming development of the telecom industry in Hong Kong makes it become a special region where global mobile users choose to use the highest number of portability business .In 1998, the relevant advisory body of telecom industry entrusted by Hong Kong Communications Authority conducted a study and analysis on the feasibility and costeffectiveness of the implementing number portability policy in Hong Kong, and studied in detail the choice of technical scheme, cost sharing and implementing process during the implementation of number portability policy.

After professional and comprehensive analysis, March 1, 1999 , Hong Kong began to implement the number portability policy, and made the following provisions with the portability business process and fee collection: (1) In terms of process about the number portability, The user need to enter the business hall ,apply and fill out the application form for the carrier's telecom operators, the carrier's telecom operators would verify the user information of original telecom operators, verified users might carry into the new telecom operators, the processing time was only one or two days.(2) In terms of transfer fee about the number portability, in the beginning implementation of the number portability policy, in order to improve the efficiency of telecom operators transacting portability business, and stimulate and promote mobile users to use the number portability business, Hong Kong applied for the use of portability business with free transfer fee. However, mobile users frequent replaced between the operators, which increased network operating burden of telecom operators. Therefore, to stabilize the stable development of the telecom market, Hong Kong began to charge a certain transfer fees with users that used the number portability business. Transfer fees were discretionarily levied according to the actual situation by the carrying party.

At that time, in the Hong Kong's mobile market, such as Hutchison Telecom, New World Mobile, China Resources, Digital, CSL and SUNDAY, the six telecom operators 
provided telecom business and services for users, mobile market competitions had been quite full, and then mobile number resources had been a public resource, no longer were monopolized by the telecom operators, to a certain extent, completely separated with the telecom operators, which provided a good basis for the effective development of portability business.

\section{B. Implementation effect of the number portability policy in Hong Kong}

After the implementation of the number portability policy in Hong Kong, the telecom operators began to play a price war, which resulted into substantial declining operating income of telecom operators. The telecom operators had taken the appropriate measures to deal with a large number of the user's off-grid after the implementation of the number portability policy, disguisedly reduced the actual level of communication charges in a variety of ways. China Resources and SCL telecom operators extended the free talk time within the package, New World Mobile operators freely provided terminal phone with the new network users. With the implementation of the number portability policy, mobile phone tariffs continued to decrease, mobile users increased from 2.8 million to 6 million in one year. Hong Kong became the best policy effect of telecom market in the world. October 2016, the number of mobile subscribers in Hong Kong had exceeded 17.14 million, and mobile phone penetration rate in the population-based was $233.4 \%$. Since the implementation of the number portability policy in 1999, using rate of the number portability business had remained around $14 \%$, reached $32 \%$ in 2001. According to the statistical data of Hong Kong Communications Authority, it could be seen from Figure 4 that the users who applied for the transfer business had been able to successfully carry out since the implementation of the number portability policy, the success rate of the portability could be maintained above $90 \%$.

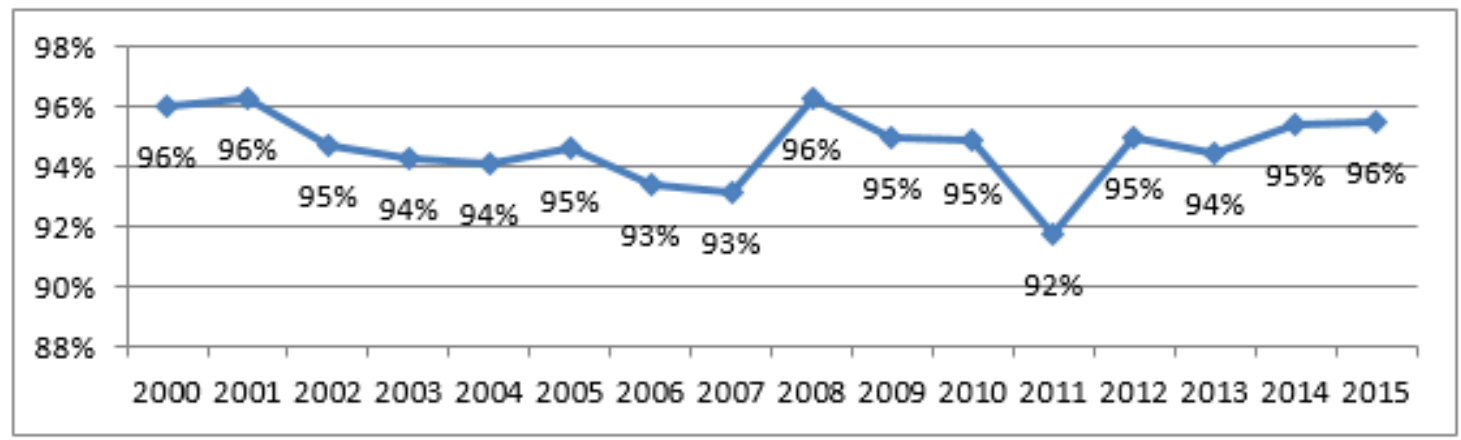

Fig. 3. The success rate of mobile number portability in Hong Kong(2000-2015)

\section{Implementation experiences of the number portability policy in Hong Kong}

The reasons why Hong Kong's telecom market can become the most active area of the number portability business are as follow: firstly, Communications Authority in Hong Kong has carried out active publicity for the number portability policy, which let the mobile users fully understand the number portability policy, and effective promote the implementation of the number portability policy. Secondly, in the process of the number portability policy implementation, Hong Kong has established a matching laws and regulations, linked the principles and procedures of portability into the legal framework, standardized the operating process of portability to ensure the users' right carrying out from their operators, provided assurance for users within the prescribed time limit to successfully use the number portability services. Finally, there are the effective supervisions of telecom regulators.

Although the telecom operators in 1999 decided to jointly adjust the telecom tariffs, Hong Kong Communications Authority made a serious warning with telecom operators' behavior, the telecom operators had finally failed to achieve the common adjustment of telecom tariff decision. After the implementation of the number portability policy, in order to promote the implementation of the number portability policy and the active use of mobile users, it is stipulated that the telecom operators would not be allowed to charge any fees with the carrier. When all mobile numbers made use of portability business, all bundled sales in the original telecom operator network would be invalid, it strictly prohibited any action that impeded the implementation of the number portability policy, in order to ensure that mobile users were free to transfer network. It was owing to the strong regulatory measures that made a large number of mobile users use the number portability business in every month, since the implementation of the number portability policy in Hong Kong.

\section{EXPERIENCE REFERENCE OF THE NUMBER PORTABILITY POLICY IN TYPICAL COUNTRIES OR REGIONS}

Although the developing level of the telecom industry and the competitive environment of the telecom market have some differences in various countries or regions, the regulatory objectives is to introduce a competitive mechanism in the telecom industry, and promote the healthy and orderly development of the telecom industry. From the implementation method and practice results of number portability policy in Japan, Korea and Hong Kong, we sum up the effective implementation experience of the number portability policy benefited China's telecom industry. 


\section{A. Comprehensive advisory mechanism of telecom industry}

The number portability policies in Japan, Korea and Hong Kong have been able to acquire better policy expectations, it is closely linked their complete advisory mechanism of telecom industry. Before implementation of the number portability policy, they establish the relevant telecom advisory body and department, or entrust other countries' telecom professional consulting research institutions to assess the costs and benefits which are induced by the implementation of the number portability policy [9]. They conduct a detailed analysis for the related business matters, in order to ensure that the implementation of the number portability policy can achieve the expected effect. During the implementation of the number portability policy, the professional telecom advisory bodies establish an evaluation system of telecom market competition, regularly conduct research with telecom market, collect and sort out relevant data, and comprehensively evaluate the telecom market competition. Based on the evaluation results, they adjust or formulate the relevant supervision policies, timely coordinate and resolve relevant problems in the telecom market competition, which ensures the legitimate rights and interests of consumers.

\section{B. Strict regulatory measures of telecom industry}

After the implementation of the number portability policy, Japan, Korea and Hong Kong focus on telecom regulation, and effectively ensure that the number portability policy can smoothly be carried out in the country. The relevant telecom regulatory authorities strictly regulate for unfair competition behaviors which hinder the effective competition of telecom market during the implementation of the number portability policy. Once the unfair competition behaviors of telecom operators are found, they timely investigate and obtain evidence, and carry out a severe punishment for a series of irregular behavior, which increases the penalties for violations of telecom operators, and strengthens the supervision of the telecom market in order to maintain the effective competition in the telecom market [10]. The strong punishments play a deterrent effect for the telecom operators, promote telecom operators to consciously abide relevant laws and regulations in the course of business, make use of legitimate business methods to enhance operators' profits, which provides a fair and effective competitive environment for the development of the telecom industry.

\section{Perfect regulations system of telecom industry}

During the implementation of the number portability policy in Japan, Korea and Hong Kong, the perfect laws and regulations play a key role with the implementation effect of the policy. These countries or regions, which have achieved good effects through the successful implementation of the number portability policy, combine the reform of the telecom industry with the legal system of the telecom industry, synthetically consider the new competitive environment of telecom industry on the basis of the original laws and regulations and make the necessary amendments. The reform of the telecom industry must be matched with the relevant laws and regulations, stipulate in detail portability business process, charging models and charging standard with the law form. The regulatory agencies analyze and research the problems which arise during the implementation of the number portability policy, include into regulations for the involved important content, specify telecom operators' behaviors which impede the effective implementation of the number portability policy in the form of legal norms, and effectively guarantee that the number portability policy can promote the formation of an effective competitive landscape in the telecommunications.

\section{CONCLUSION}

After the implementation of the number portability policy, Hong Kong is the most active region in the telecom market, Japan and Korea are less than Hong Kong in the telecom market activity, but play a certain positive role in reducing the market share of the leading telecom operators and the formation of effective competition pattern in the telecom market. In comparison, these countries or regions implement the number portability policy through the research and analysis of the regulatory bodies and professional advisory body, promote the country to do a detailed provision in the form of laws and regulations from the business processes, charge standard and time limit of business processing, regularly assess and review the policy implementation effect, timely deal with and solve problem arising in the process of the policy implementation process, and severely punish behaviors impeding the implementation of the number portability policy and telecom market competition .

\section{REFERENCES}

[1] Buehler S, Haucap J. Mobile Number Portability[J]. Journal of Industry Competition \& Trade, 2004, 4(3):223-238

[2] Yao chenglin. Implementation of the the number portability policy and think[J].Guangdong Communication Technology, 2014, 34(10):23-26(In Chinese).

[3] Zhang dakun, Zhang xiangjin.Research on policy and strategy of international number portability business [J]. Telecom Network Technology, 2013(2):21-24(In Chinese).

[4] Yang xi.The impact of foreign numbers portability policy on the market[J]. World Telecommunications, 2010(11):27-31(In Chinese).

[5] Zhang li. The international experience and enlightenment of the number portability policy[J]. Chinese New Communication, 2011, 13(9):4851(In Chinese).

[6] Otsuka T, Mitomo H. User benefits and operator costs of mobile number portability in Japan and impact on market competitiveness[J].Telecommunications Policy,2013,37(4):345-356.

[7] Wu haijing. Explain "Number portability policy"in Korean[J].Communication World, 2004(10):26-27 (In Chinese).

[8] Kim M K, Park M C, Jeong D H. The effects of customer satisfaction and switching barrier on customer loyalty in Korean mobile telecommunication services[J]. Telecommunications Policy, 2004, 28(2):145-159.

[9] Shin D H. A study of mobile number portability effects in the United States[J]. Telematics \& Informatics, 2007, 24(1):1-14.

[10] Buehler S, Dewenter R, Haucap J. Mobile number portability in Europe[J]. Ssrn Electronic Journal, 2005, 30(7):385-399. 